\title{
Strategi Marketing Mix Home Industry Pengrajin Gula Kelapa Sebagai Pengembangan Produk Lokal di Kecamatan Jeruklegi
}

\author{
Marketing Mix Home Industry Strategy for Coconut Sugar Craftsmen as Local Product \\ Development in Jeruklegi District
}

Sulistyani Budiningsih ${ }^{1}$, Rahmi Hayati Putri ${ }^{2}$

${ }^{1,2}$ Program Studi Agribisnis Fakultas Pertanian dan Perikanan

Universitas Muhammadiyah Purwokerto

\section{ARTICLE INFO \\ Article history: \\ DOI: \\ 10.30595/pspfs.v2i.214}

Submitted:

July 29, 2021

Accepted:

Sept 10, 2021

Published:

Nov 10, 2021

\section{Keywords:}

Strategy, Home Industry, Marketing Mix, Coconut Sugar

\begin{abstract}
Research objectives: 1) Identify internal factors (strengths-weaknesses) and external (opportunities-threats) that affect the home marketing mix of coconut sugar industry in Jeruklegi District. 2) Analyzing alternative marketing mix strategies for the coconut sugar home industry in Jeruklegi District. 3) Analyzing the best marketing mix strategies that are priorities to be applied to the coconut sugar home industry in Jeruklegi District. The method used is a descriptive method with the research location in Jeruklegi District which was determined intentionally (Purposive Sampling) with certain selection considerations. Involving 25 respondents of coconut sugar craftsmen. The formulation of the home marketing mix strategy for the coconut sugar industry was analyzed by SWOT (Strengths, Weaknesses, Opportunities, Threats). (Rangkuti, 2006). The results showed that internal factors were the availability of coconut trees, coconut sugar production activities were carried out continuously, the location of the coconut sugar processing business was quite strategic, the price of coconut sugar products was able to compete, the availability of experienced workers in the coconut sugar processing business, ownership of business capital. craftsmen independently, limited number of coconut trees, product quality does not yet have uniformity (taste, color and shape), lack of marketing information sources, level of production and packaging technology is still traditional, limited working capital of craftsmen, craftsmen have not done bookkeeping management and there is no group / cooperative. The position of the coconut sugar home industry in the Jeruklegi District, Cilacap Regency is in the Aggressive Region with the main strategy being the SO strategy, namely 1) Optimizing geographical conditions that support the agroclimate of natural resources and human resources of craftsmen in producing coconut sugar products continuously with competitive prices for coconut sugar products, 2) Optimizing production activities continuously in order to capture high market share opportunities both domestically and internationally with competitive prices as substitute products through partnership relationships between coconut sugar producers.
\end{abstract}

This work is licensed under a Creative Commons Attribution 4.0 International License.

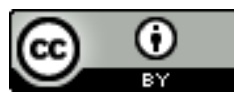

Corresponding Author:

Sulistyani Budiningsih

Program Studi Agribisnis Fakultas Pertanian dan Perikanan

Universitas Muhammadiyah Purwokerto

Proceedings homepage: https://conferenceproceedings.ump.ac.id/index.php/pspfs/issue/view/9 


\section{PENDAhuluan}

Sektor pertanian terdiri dari subsektor tanaman bahan makanan, perkebunan, perikanan, peternakan dan kehutanan yang masing masing subsektor memiliki peran dan potensi dalam membangun perekonomian Indonesia. Salah satu subsektor perkebunan berupa pohon kelapa yang bahan baku niranya bisa menjadi olahan produk lokal gula kelapa yang sampai saat ini telah memberikan potensi keuntungan bagi pengembangan ekonomi di perdesaan. Industri rumahan (home industri) produk gula kelapa adalah tergolong usaha mikro di wilayah Kabupaten Cilacap yang saat ini industri olahan kelapa terdapat menyebar di wilayah 22 kecamatan. Selanjutnya berdasarkan informasi Dinas Pangan Dan Perkebunan Kabupaten Cilacap (Tahun 2019) luas lahan pohon kelapa tercatat 5018,8 hektar dengan jumlah produk gula kelapa 44.976.311 ton/thn. Lebih rinci dapat diketahui bahwa data total Kecamatan Jeruklegi menunjukkan jumlah luas lahan pengrajin gula kelapa telah mencapai 607.5 hektar dengan total produksi gula kelapa 5.467.500 ton. Aktivitas olahan gula kelapa berbahan baku nira di Kecamatan Jeruk Legi merupakan mata pencaharian dari sebagian masyarakatnya guna pemenuhan kebutuhan hidup primer pengrajin sehari hari.

Sejalan dengan hasil penelitian Budiningsih, dkk., (2018) bahwa meski usaha pengolahan gula kelapa di Kecamatan Cilongok hanya cukup mencukupi kebutuhan sehari hari, namun pelaku pengrajin gula kelapa cukup memiliki semangat untuk terus menekuni usaha olahan gula kelapa yang sudah merupakan mata pencaharian utama sekaligus merupakan warisan usaha orang tua yang sudah puluhan tahun digeluti dengan metode pengolahan secara tradisional. Produk gula kelapa memiliki potensi untuk dikembangkan karena manfaatnya tidak hanya untuk memenuhi kebutuhan rumah tangga namun juga untuk industri lain seperti industri kecap, industri makanan dan industri jamu. Meski demikian dalam perkembangannya industri olahan gula kelapa faktanya masih menghadapi berbagai hambatan antara lain keterbatasan teknologi yang digunakan, kualitas SDM yang dimiliki , serta pada aspek pemasaran yang belum menggembirakan bagi pihak pengrajin. Ditinjau dari aspek pemasaran hal yang seringkali dijumpai pengrajin tidak punya kekuatan posisi tawar dalam menentukan harga produk, ini terkait adanya beberapa permasalahan ekonomi dan non ekonomi yang dihadapi.

Sebagaimana hasil penelitian Budiningsih dkk., (2018) yaitu harga produk ditentukan sepenuhnya oleh pedagang pengepul, 20 responden (100\%) menyatakan bahwa penentu harga gula kelapa pihak pedagang pengepul yang berasal dari wilayah sekitar Desa Kasegeran Kecamatan Cilongok Keseluruhan responden 20 $(100 \%)$ wirausaha pengrajin gula kelapa menyatakan kegiatan pengolahan masih secara tradisional dengan keterbatasan kepemilikan modal usaha, ditunjukkan adanya kesulitan memperoleh modal usaha untuk produksi terutama modal untuk pembelian kayu bakar yang semakin mahal harganya. Terlebih pendapatan yang diperoleh langsung digunakan memenuhi kebutuhan sehari hari bahkan seringkali pengrajin meminjam uang (modal) usaha kepada para pedagang pengepul.

Dengan demikian sangat diperlukan kebijakan komprehensif (menyeluruh) dari mulai hulu sampai hilir yaitu penyedia bahan baku sampai dengan pemasaran (marketing mix) serta dukungan SDM, teknologi, sarana prasarana, kemitraan antara agroindustri skala besar/sedang dengan agroindustri skala kecil/rumah tangga (Supriyati dan Suryani, 2006 dalam Ahmad dan Priyono, 2012). Lebih lanjut pengrajin perlu melakukan strategi bauran pemasaran (marketing mix) dengan mengembangkan suatu produk (product) yang memuaskan konsumen dan menawarkan produk tersebut pada harga (price) tertentu serta mendistribusikannya pada tempat tempat (place) yang menjadi pasar produk serta kegiatan promosi (promotion) agar konsumen tertarik (Kotler, 2005).

Perlu diindentifikasi faktor lingkungan internal (kekuatan-kelemahan) dan eksternal (peluang-ancaman) yang mempengaruhi marketing mix home industri pengrajin gula kelapa di wilayah Kecamatan Cilacap sekaligus menyusun strategi marketing mix guna pengembangan produk olahan lokal bagi pengrajin gula kelapa. Oleh karena itu penelitian ini menjadi penting dilakukan untuk menyusun strategi marketing mix terbaik yang menjadi prioritas untuk diterapkan pada home industri pengrajin gula kelapa guna pengembangan produk olahan lokal di Kecamatan Jeruklegi.

Bertolak dari latar belakang pentingnya penelitian strategi marketing mix home industri pengrajin gula kelapa guna pengembangan produk olahan lokal di Kecamatan Jeruklegi, maka dirumuskan permasalahan sebagai berikut : (1) Bagaimanakah faktor lingkungan internal (kekuatan-kelemahan) dan eksternal (peluangancaman) yang mempengaruhi marketing mix home industry pengrajin gula kelapa guna pengembangan produk olahan lokal di Kecamatan Jeruklegi ? (2) Bagaimanakah alternatif strategi marketing mix home industri gula kelapa berdasarkan kesesuaian faktor lingkungan internal (kekuatan-kelemahan) dan lingkungan eksternal (peluang-ancaman) di Kecamatan Jeruklegi ? (3) Bagaimanakah strategi marketing mix terbaik yang menjadi prioritas untuk diterapkan pada home industri pengrajin gula kelapa guna pengembangan produk olahan lokal di Kecamatan Jeruklegi?

\section{METODE PENELITIAN}

Metode yang digunakan berupa metode deskriptif sebagai penelitian yang hanya menunjukkan gambaran, uraian ata rincian tentang gejala atau obyek yang akan diteliti (Mardikanto, 2011). Waktu penelitian 
dilakukan pada bulan Waktu penelitian telah berlangsung dilaksanakan dari bulan Nopember 2020 s/d Juni pada tahun 2021

Lokasi penelitian di Kecamatan Jeruklegi Kabupaten Cilacap yang ditetapkan secara sengaja (Purposive Sampling) dengan pertimbangan pemilihan lokasi berdasarkan pada potensi sumberdaya lokal yang dimiliki berupa pohon kelapa yang tersebar di sejumlah wilayah desa di Kecamatan Jeruk Legi dan terdapatnya home industri pengrajin gula kelapa berbahan baku nira sebagai sumber mata pencaharian sehari hari penduduk perdesaan di wilayah Kecamatan Jeruklegi.

Penentuan pengambilan sampel desa di Kecamatan Jeruklegi dilakukan secara simple random sampling (Sampel Acak Sederhana) sehingga terpilih dua (2) desa yaitu Desa Karangkemiri dengan 85 pengrajin gula kelapa dan Desa Jambusari yang memiliki 24 pengrajin gula kelapa. Jumlah sampel penelitian ditetapkan secara sengaja (Purposive Sampling) pula sebanyak 25 pengrajin gula kelapa dengan rincian 15 pengrajin dari Desa Karangkemiri dan 10 pengrajin dari Desa Jambusari dengan pertimbangan sudah lebih dari 3 tahun menekuni profesi mengolah nira menjadi produk gula kelapa sekaligus merupakan mata pencaharian utama sehari - sehari yang diwarisi secara turun temurun dengan omset produksi minimal 2,5 kg gula kelapa per hari.

Jenis data yang diambil adalah data primer dan data sekunder. Dalam mengumpulkan data primer dan sekunder dilakukan dengan teknik wawancara, observasi dan dokumentasi.

Rumusan strategi marketing mix home industri pengrajin gula kelapa sebagai pengembangan produk olahan lokal dianalisis menggunakan analisis SWOT (Strengths, Weaknesses, Opportunities, Threats). (Rangkuti, 2006). Langkah analisis strategi marketing mix home industri pengrajin gula kelapa di Kecamatan Jeruklegi adalah : (1) Analisis SWOT (Strengths, Weaknesses, Opportunities, Threats) untuk mengidentifikasi faktor lingkungan internal dan eksternal, (2) Matriks Space untuk melihat posisi strategis home industri pengrajin gula kelapa, (3) Matriks SWOT merupakan analisis yang menggambarkan kekuatan, kelemahan, peluang dan ancaman guna merumuskan strategi marketing mix home industri pengrajin gula kelapa.

\section{HASIL DAN PEMBAHASAN}

\section{Analisis SWOT Home Industri Gula Kelapa di Kecamatan Jeruk Legi}

Strategi pengembangan marketing mix home industri gula kelapa di Kecamatan Jeruk Legi Kabupaten Cilacap didasarkan pada identifikasi faktor lingkungan internal (kekuatan - kelemahan) dan eksternal (peluang ancaman), untuk menyusun strategi marketing mix home industri pengrajin gula kelapa sebagai produk olahan lokal di Kecamatan Jeruk Legi Kabupaten Cilacap. Berdasakan analisis SWOT (Strength, Weakness, Opportunities, Threats) yang dievaluasi menggunakan IFAS dan EFAS, home industri gula kelapa di Kecamatan Jeruk Legi memiliki potensi besar untuk dikembangkan. Hasil tersebut didasarkan atas pertimbangan faktor kekuatan dan peluang yang lebih dominan dari pada kelemahan dan ancamannya

\section{Kekuatan}

Kekuatan yang menjadi kunci antara lain ketersediaan bahan baku nira dan teknik pengolahan yang mudah dengan teknologi sederhana yang mempengaruhi kontinuitas kegiatan pengolahan gula kelapa bisa dilakukan tiap hari. Hasil tersebut didukung pernyataan Sugiyowati (2014) dalam Pudyastuti (2019) yang menyebutkan bahwa ketersediaan bahan baku yang mudah dinyatakan sebagai faktor paling penting.dalam pengembangan agroindustri gula aren. Produksi gula kelapa di Kecamatan Jeruklegi dilakukan tiap hari sehingga akan menjaga ketersediaan produk

\section{Kelemahan}

Keterbatasan modal yang dimiliki pengrajin pada umumnya di lokasi penelitian dan dibarengi dengan penggunakan teknologi sederhana / tradisional dalam mengolah bahan baku nira menjadi produk gula kelapa merupakan kelemahan yang dimiliki pengraji sehingga cenderung sangat menggantungkan kepada pengepul dalam memasarkan gula kelapa ataupun apabila pengrajinmembutuhkan dana sewaktu waktu, meskipun pihak penegepul yang menentukan harga. Sebagaimana dikemukakan Umar (2016) bahwa modal yang cukup sangat dibutuhkan dalam upaya peningkatan kualitas dan kuantitas produksi gula kelapa. Lebih lanjut dijelaskan faktor kelemahan berupa keterbatasan modal menyebabkan pengrajin berada pada posisi tawar yang lemah. Posisi tawar yang lemah dibarengi aksesibilitas kurangnya informasi pasar pihak pengrajin tentang harga pasar (aspek harga).

\section{Peluang}

Harga produk gula kelapa di Kecamatan Jeruklegi mampu bersaing dengan produk gula kelapa dari wilayah lain, kondisi ini tentunya menjadi peluang bagi pengrajin gula kelapa untuk meningkatkan produksi. Disi lain terdapat peluang pasar olahan gula kelapa cukup tinggi baik pasar domestik maupun internasional. Selama ini dalam pemasaran gula kelapa pengrajin juga didukung terdapatnya hubungan kemitraan antar pelaku pengrajin gula kelapa dan hubungan dengan pihak tengkulak. Senada pernyataan tersebut Azhari dkk (2016) menyatakan bahwa suatu industri yang memanfaatkan peluang dengan baik akan mampu bertahan dalam persaingan serta mendorong adanya pengembangan usaha. 
Pihak PEMDA setempat dan instansi terkait memang pernah melakukan pembinaan secara insidental terhadap para pengrajin gula kelapa di wilayah Kecamatan Jeruklegi, padahal mereka masih memerlukan pembinaan secara intensif untuk mengembangkan usaha olahan gula kelapa. Merujuk Isnaini dkk (2011) dalam Pudyastuti dkk., (2019) yang menyatakan bahwa pembinaan intensif bagi pengusaha gula kelapa sangat mempengaruhi dalam pengembangn usahanya. Selain itu usaha pengrajin di wilayah penelitian juga belum didukung keberadaan kelompok pengrajin gula kelapa / koperasi produk gula kelapa secara bersama. Padahal dengan adanya kelompok atau koperasi akan sangat memudahkan pengrajin dalam mengembangkan usaha olahan gula kelapa menjadi lebih meningkat kualitas dan kuantitas guna mencapai kesejahteraan hidup pegrajin. Sebagaimana dikemukakan Syahza (2012) bahwa peran koperasi sangat penting dalam pengembangan usaha dan kesejahteraan masyarakat.

\section{Analisis SWOT ( Strength, Weakness, Opportunities, Threats ) Home Industry Gula Kelapa di Kecamatan Jeruklegi Kabupaten Cilacap.}

Strategi pengembangan pemasaran home industri gula kelapa di Kecamatan Jeruklegi Kabupaten Cilacap didasarkan pada identifikasi faktor lingkungan internal (kekuatan-kelemahan) dan eksternal (peluang-ancaman), sehingga dapat digunakan untuk menyusun strategi pengembangan marketing mix home industri pengrajin gula kelapa guna pengembangan produk olahan lokal di Kecamatan Jeruklegi Kabupaten Cilacap.

Berdasarkan analisis SWOT yang dievaluasi menggunakan IFAS dan EFAS, home industri gula kelapa di Kecamatan Jeruklegi memiliki potensi besar untuk dikembangkan. Hasil tersebut didasarkan atas pertimbangan faktor kekuatan dan peluang yang lebih dominan dari pada kelemahan dan ancamannya. Setelah dilakukan identifikasi analisis faktor internal dan eksternal ini selanjutnya hasil identifikasi digunakan untuk menyusun matriks IFAS (Internal Factors Analysis Summary) dan EFAS ( Eksternal Factors Analysis Summary). Secara lengkap hasil analisis matriks IFAS dan EFAS tersebut disajikan pada Tabel 5 dan Tabel 6 dibawah ini .

Tabel 1. Analisis Faktor - Faktor Internal (Kekuatan dan Kelemahan) Home Industry Pengrajin Gula Kelapa di Kecamatan Jeruklegi Kabupaten Cilacap

\begin{tabular}{|c|c|c|c|c|}
\hline No. & Faktor-Faktor Strategi Internal & Rating & Bobot & $\begin{array}{l}\text { Bobot x } \\
\text { Rating }\end{array}$ \\
\hline \multicolumn{5}{|c|}{ KEKUATAN } \\
\hline 1. & Tersedianya pohon kelapa yang diambil niranya. & 3,620 & 0.915 & 3.312 \\
\hline 2. & Tersedianya tenaga kerja pengrajin gula kelapa & 3,624 & 0.085 & 0.308 \\
\hline 3. & $\begin{array}{l}\text { Kegiatan produksi gula kelapa dilakukan secara } \\
\text { kontinue }\end{array}$ & 3,465 & 0.081 & 0.306 \\
\hline 4. & $\begin{array}{l}\text { Ketrampilan pengrajin gula kelapa diperoleh } \\
\text { secara turun temurun }\end{array}$ & 3,624 & 0.086 & 0.337 \\
\hline 5. & $\begin{array}{l}\text { Lokasi usaha olahan gula kelapa yang cukup } \\
\text { strategis }\end{array}$ & 3,698 & 0.088 & 0.355 \\
\hline 6. & $\begin{array}{l}\text { Pengalaman pengrajin yang sudah lama } \\
\text { menekuni usaha olahan gula kelapa }\end{array}$ & 3,200 & 0.075 & 0.240 \\
\hline 7. & Harga produk gula kelapa mampu bersaing & 3,465 & 0.081 & 0.281 \\
\hline \multicolumn{5}{|c|}{ KELEMAHAN } \\
\hline 1. & Keterbatasan jumlah pohon kelapa pengrajin & 2,548 & 0.062 & 0.175 \\
\hline 2. & $\begin{array}{l}\text { Kualitas produk belum memiliki keseragaman } \\
\text { (rasa, warna dan bentuk cetakan) }\end{array}$ & 2,862 & 0.068 & 0.201 \\
\hline
\end{tabular}
(rasa, warna dan bentuk cetakan)

$\begin{array}{llllll}\text { 3. } & \text { Tingkat teknologi produksi dan pengemasan } & 2,754 & 0.066 & 0.195 \\ \text { secara tradisional }\end{array}$




$\begin{array}{lllll}\text { 4. } \begin{array}{l}\text { Keterbatasan modal usaha yang dimiliki } \\ \text { pengrajin }\end{array} & 2,720 & 0.064 & 0.186 \\ 5 & \begin{array}{l}\text { Pengrajin belum melakukan manajemen } \\ \text { pembukuan dalam usaha gula kelapa }\end{array} & 2,628 & 0.063 & 0.177 \\ \text { Minimnya sumber informasi pemasaran } \\ \text { sehingga produk gula kelapa dijual ke tengkulak } \\ \begin{array}{l}\text { Belum terdapatnya kesadaran para pengrajin } \\ \text { membentuk kelompok guna pengembangan } \\ \text { usahanya }\end{array} & 2,240 & 0.053 & 0.103 \\ \end{array}$

Sumber : Olahan Data Primer, 2021.

Analisis faktor faktor eksternal berupa peluang dan ancaman bagi home industri pengrajin gula kelapa di Kecamatan Jeruklegi diuraikan Tabel 6.

Tabel 2. Analisis Faktor - Faktor Eksternal (Peluang Dan Ancaman) Responden Pengrajin Gula Kelapa di Kecamatan Jeruklegi Kabupaten Cilacap

\begin{tabular}{|c|c|c|c|c|}
\hline No. & Faktor-Faktor Strategi Eksternal & Rating & Bobot & $\begin{array}{l}\text { Bobot } \mathrm{x} \\
\text { Rating }\end{array}$ \\
\hline \multicolumn{5}{|c|}{ PELUANG } \\
\hline 1. & $\begin{array}{l}\text { Kondisi geografis yang } \\
\text { agroklimat pohon kelapa }\end{array}$ & 3,289 & 0.104 & 0.342 \\
\hline 2. & $\begin{array}{l}\text { Peluang pasar olahan gula kelapa cukup tinggi } \\
\text { baik pasar domestik maupun internasional }\end{array}$ & 2,852 & 0.093 & 0.265 \\
\hline 3. & $\begin{array}{l}\text { Produk gula kelapa sebagai produk substitusi } \\
\text { gula pasir/gula aren }\end{array}$ & 2,960 & 0.096 & 0.309 \\
\hline 4. & $\begin{array}{l}\text { Terdapatnya hubungan kemitraan antar pelaku } \\
\text { pengrajin gula kelapa }\end{array}$ & 3,194 & 0.104 & 0.364 \\
\hline 5. & $\begin{array}{l}\text { Terdapatnya pembinaan/kebijakan PEMDA } \\
\text { dan instans terkait dalam mendukung } \\
\text { pengembangan tanaman kelapa }\end{array}$ & 2,880 & 0.091 & 0.262 \\
\hline \multicolumn{5}{|c|}{ ANCAMAN } \\
\hline 1. & $\begin{array}{l}\text { Adanya perubahan iklim yang mempengaruhi } \\
\text { kualitas nira }\end{array}$ & 2,555 & 0.081 & 0.228 \\
\hline 2. & $\begin{array}{l}\text { Terdapatnya produk olahan gula kelapa yang } \\
\text { dihasilkan pengrajin dari luar wilayah }\end{array}$ & 2,902 & 0.094 & 0.294 \\
\hline 3. & $\begin{array}{l}\text { Pembinaan terhadap pengrajin gula kelapa } \\
\text { oleh pihak PEMDA dan instansi terkait } \\
\text { bersifat insidental }\end{array}$ & 2,756 & 0.087 & 0.239 \\
\hline 4. & $\begin{array}{l}\text { Harga produk ditentukan sepihak oleh } \\
\text { pengepul sehingga pengrajin sebagai penerima } \\
\text { harga }\end{array}$ & 2,830 & 0.089 & 0.273 \\
\hline \multirow[t]{2}{*}{5.} & $\begin{array}{l}\text { Belum terbentuknya kelompok pengrajin gula } \\
\text { kelapa atau asosiasi untuk pemasaran bersama }\end{array}$ & 2,513 & 0.079 & 0.198 \\
\hline & TOTAL NILAI & & 1,000 & \\
\hline
\end{tabular}

Sumber : Olahan Data Primer, 2021.

Hasil analisis faktor internal dan eksternal pada Tabel 5 dan Tabel 6 selanjutnya ditentukan beberapa strategi yang digunakan untuk memecahkan persoalan persoalan yang dihadapi para pengrajin gula kelapa sehingga strategi home industri gula kelapa di Kecamatan Jeruklegi Kabupaten Cilacap dapat diketahui. Berdasarkan hasil analisis dengan IFAS (Internal Factors Analysis Summary) menunjukkan nilai sebesar 3,0698 dan EFAS ( Eksternal Factors Analysis Summary) menunjukkan nilai sebesar 3, 7198. Hasil analisis faktor internal pada Tabel 1 dan faktor eksternal pada Tabel 2 selanjutnya dapat ditentukan beberapa strategi 
pemasaran yang digunakan untuk memecahkan persoalan persoalan yang dihadapi pengrajin home industri gula kelapa di Kecamatan Jeruklegi Kabupaten Cilacap. Diawali dengan pembuatan Matrik Space Analysis kemudian digunakan sebagai dasar untuk menyusun Matrik SWOT seperti tertera pada Tabel 3 dibawah ini.

Penentuan koordinat dalam diagram analisis SWOT berfungsi untuk menentukan posisi apakah terletak pada kuadran I,II,III dan IV. Hal ini akan berfungsi untuk mengidentifikasi apakah strategi perusahaan bersifat Agresif, Diversifikasi, Turn Around atau Detensif. Dari hasil Matrik SWOT yang telah dilakukan menggambarkan posisi home industri pengrajin gula kelapa di Kecamatan Jeruklegi Kabupaten Banyumas pada fase agresif di Kuadran I yang merupakan pertemuan faktor internal dengan faktor eksternal terdapat pada koordinat $(0,956: 0,324)$. Pada fase ini strategi yang yang dapat diterapkan adalah strategi SO/Agresif yang menggunakan seluruh kekuatan untuk memanfaatkan peluang yang ada.

Tabel 3. Matrik SWOT Home Industri Pengrajin Gula Kelapa di Wilayah Kecamatan Jeruklegi Kabupaten Cilacap

\begin{tabular}{|c|c|c|}
\hline & STRENGTHS (S) & WEAKNESSES (W) \\
\hline EFAS & $\begin{array}{l}\text { Tersedianya pohon kelapa yang } \\
\text { diambil niranya. } \\
\text { Tersedianya tenaga kerja } \\
\text { pengrajin gula kelapa } \\
\text { Kegiatan produksi gula kelapa } \\
\text { dilakukan secara kontinue } \\
\text { Kepemilikan modal usaha } \\
\text { pengrajin secara mandiri } \\
\text { Lokasi usaha olahan gula kelapa } \\
\text { yang cukup strategis } \\
\text { Pengalaman pengrajin yang } \\
\text { sudah lama menekuni usaha } \\
\text { olahan gula kelapa } \\
\text { Harga produk gula kelapa } \\
\text { mampu bersaing }\end{array}$ & $\begin{array}{l}\text { Keterbatasan jumlah pohon } \\
\text { kelapa pengrajin } \\
\text { Kualitas produk belum memiliki } \\
\text { keseragaman (rasa, warna dan } \\
\text { bentuk cetakan) } \\
\text { Tingkat teknologi produksi dan } \\
\text { pengemasan produk secara } \\
\text { tradisional } \\
\text { Keterbatasan modal usaha yang } \\
\text { dimiliki pengrajin } \\
\text { Pengrajin belum melakukan } \\
\text { manajemen pembukuan dalam } \\
\text { usaha gula kelapa } \\
\text { Minimnya sumber informasi } \\
\text { pemasaran sehingga produk gula } \\
\text { kelapa dijual ke tengkulak } \\
\text { Belum terdapatnya kesadaran para } \\
\text { pengrajin membentuk kelompok } \\
\text { guna pengembangan usahanya }\end{array}$ \\
\hline
\end{tabular}

\begin{tabular}{|c|c|c|}
\hline OPPORTUNITIES (O) & STRATEGI SO & STRATEGI WO \\
\hline $\begin{array}{l}\text { Kondisi geografis yang } \\
\text { mendukung agroklimat pohon } \\
\text { kelapa } \\
\text { Peluang pasar olahan gula } \\
\text { kelapa cukup tinggi baik pasar } \\
\text { domestik maupun internasional } \\
\text { Produk gula kelapa sebagai } \\
\text { produk substitusi gula pasir/gula } \\
\text { aren }\end{array}$ & $\begin{array}{l}\text { Mengoptimalkan kondisi } \\
\text { geografis yang mendukung } \\
\text { agroklimat SDA dan SDM } \\
\text { pengrajin dalam memproduksi } \\
\text { produk gula kelapa secara } \\
\text { kontinue dengan harga produk } \\
\text { gula kelapa mampu bersaing } \\
(\mathrm{S} 1, \mathrm{~S} 2, \mathrm{~S} 3, \mathrm{~S} 6, \mathrm{O} 1, \mathrm{O} 4, \mathrm{O} 5, \mathrm{~S} 7)\end{array}$ & $\begin{array}{l}\text { Pelatihan oleh pihak PEMDA dan } \\
\text { instansi terkait untuk lebih } \\
\text { meningkatkan ketrampilan } \\
\text { pengrajin dalam teknologi } \\
\text { produksi guna mendapatkan } \\
\text { keseragaman kualitas produk dan } \\
\text { pengemasan produk serta } \\
\text { manajemen pembukuan usaha } \\
\text { (W2,W3, W5, O5) } \\
\text { Pembentukan kelompok atau }\end{array}$ \\
\hline $\begin{array}{l}\text { Terdapatnya hubungan } \\
\text { kemitraan antar pelaku } \\
\text { pengrajin gula kelapa } \\
\text { Terdapatnya pembinaan / } \\
\text { kebijakan PEMDA dan instansi } \\
\text { terkait dalam mendukung } \\
\text { pengembangan olahan gula } \\
\text { kelapa }\end{array}$ & $\begin{array}{l}\text { Mengoptimalkan kegiatan } \\
\text { produksi secara kontinue } \\
\text { dengan peluang pangsa pasar } \\
\text { tinggi baik domestik dan } \\
\text { internasional serta harga } \\
\text { bersaing sebagai produk } \\
\text { substitusi melalui hubungan } \\
\text { kemitraan antar pelaku }\end{array}$ & $\begin{array}{l}\text { koperasi pengrajin gula kelapa } \\
\text { sebagai wadah belajar pengrajin } \\
\text { mendapat informasi pemasaran } \\
\text { guna menangkap peluang pasar } \\
\text { cukup tinggi (Domestik dan } \\
\text { Internasional) } \\
(\mathrm{W} 6, \mathrm{~W} 7, \mathrm{O} 2, \mathrm{O} 5)\end{array}$ \\
\hline
\end{tabular}


pengrajin gula kelapa

(S3,S7, O2,O3, O4)

THREATHS (T)

Adanya perubahan iklim yang mempengaruhi kualitas nira

Terdapatnya produk olahan gula kelapa yang dihasilkan pengrajin dari luar wilayah

Pembinaan terhadap pengrajin gula kelapa oleh pihak PEMDA dan instansi terkait bersifat insidental

Harga produk ditentukan sepihak oleh pengepul sehingga pengrajin sebagai penerima harga

Belum terbentuknya kelompok pengrajin gula kelapa atau asosiasi untuk pemasaran bersama Sumber : Olahan Data Primer, 2021.

Tahap terakhir berupa tahap pengambilan keputusan yang bertujuan untuk menyusun strategi yang telah digambarkan oleh matrik SWOT sehingga strategi yang muncul dapat dijadikan acuan untuk dapat meningkatkan strategi pengembangan home industri gula kelapa di Kecamatan Jeruklegi Kabupaten Cilacap. Oleh karena hasil analisis menunjukkan bahwa kondisi home industri pengrajin gula kelapa berada pada strategi SO (Strenghts Opportunities), yaitu memanfaatkan kekuatan untuk meningkatkan peluang. Hal ini didasarkan hasil kajian Karmiati dkk (2016) yang menyebutkan bahwa penggunaan alternatif strategi untuk mendukung pengembangan agroindustri gula tumbu adalah strategi S-O yaitu mendukung pertumbuhan agresif. Oleh karena itu strategi ini menjadi strategi prioritas. Adapun beberapa alternatif strategi yang dapat dilakukan pada home industri gula kelapa di Kecamatan Jeruklegi Kabupaten Cilacap adalah:

\section{Strategi (S-O)}

Strategi SO merupakan sebuah strategi yang menggunakan kekuatan yang dimiliki untuk mendapatkan peluang yang ada. Strategi SO yang dapat diterapkan pada home industri pengrajin gula kelapa di Kecamatan Jeruklegi adalah:

1. Mengoptimalkan kondisi geografis yang mendukung agroklimat SDA dan SDM pengrajin dalam memproduksi produk gula kelapa secara kontinue dengan harga produk gula kelapa yang mampu bersaing

a. Memaksimalkan ketersediaan bahan baku nira untuk memanfaatkan peluang menjadikan olahan produk gula kelapa dengan harga bersaing

b. Meningkatkan kualitas tenaga kerja SDM pengrajin melalui kegiatan pelatihan dan ketrampilan guna menghasilkan peningkatan produk gula kelapa bagi pengrajin.

2. Mengoptimalkan kegiatan produksi secara kontinue guna menangkap peluang pangsa pasar tinggi baik domestik dan internasional dengan harga bersaing sebagai produk substitusi melalui hubungan kemitraan antar pelaku pengrajin gula kelapa

a. Melaksanakan efisiensi pengelolaan bahan baku nira guna menciptakan produk gula kelapa beragam (mutu, rasa, bentuk seragam) dan melakukan standarisasi pengolahan produk gula kelapa agar mampu bersaing di pasar domestik dan internasional.

b. Mengembangkan terciptanya kemitraan kelembagaan antara pengrajin, saluran pemasaran / pedagang dan pemerintah.

\section{Strategi S-T}

Strategi S-T merupakan sebuah strategi yang menggunakan kekuatan yang dimiliki home industri gula kelapa untuk menghindari ancaman. Adapun strategi yang dapat diterapkan pada home industri gula kelapa di Kecamatan Jeruklegi ini adalah: 
1. Optimalisasi aktivitas produksi gula kelapa berbahan baku nira secara kontinue dilakukan meski terjadi perubahan iklim yang mempengaruhi kualitas nira.

a. Melakukan intensifikasi, ekstensifikasi dan diversifikasi olahan produk seperti mengolah gula semut dengan harga lebih tinggi.

b. Melakukan kegiatan standarisasi produk dan pengawasan produk gula kelapa

2. Peningkatan posisi tawar bagi pengrajin gula kelapa untuk bisa bersaing dengan produk dari pengrajin diluar wilayah

a. Memberikan penguatan akses informasi dan jaringan pemasaran kepada para pengrajin gula kelapa guna memperkuat posisi tawar .

b. Memfasilitasi penyaluran subsidi permodalan usaha gula kelapa guna menghindari ketergantungan modal kepada pihak pengepul.

\section{Strategi W-O}

Strategi W-O merupakan strategi yang dilaksanakan dengan cara meminimalkan kelemahan dengan memanfaatkan peluang yang ada. Adapun strategi WO yang dapat diterapkan pada home industri gula kelapa di Kecamatan Jeruklegi adalah :

1. Pelatihan oleh pihak PEMDA dan instansi terkait untuk lebih meningkatkan ketrampilan pengrajin dalam teknologi produksi guna mendapatkan keseragaman kualitas produk dan pengemasan produk sekaligus ketrampilan manajemen pembukuan usaha .

a. Pengrajin secara rutin dan berkala mengikuti kegiatan pelatihan yang diselenggarakan pihak Pemda setempat/instansi terkait tentang teknologi produksi dan pengemasan produk.

b. Pengrajin mengikuti pembinaan dan pelatihan dari pihak Pemda setempat/instansi terkait ketrampilan manajemen pembukuan usaha.

2. Pembentukan kelompok atau koperasi pengrajin gula kelapa sebagai wadah belajar pengrajin mendapat informasi pemasaran guna menangkap peluang pasar cukup tinggi (Domestik dan Internasional)

a. Membentuk kelompok/koperasi pengrajin gula kelapa untuk memperkuat posisi tawar pengrajin, mendapatkan akses informasi pemasaran secara lengkap sekaligus memperluas pangsa pasar produk gula kelapa. Sebagaimana yang dikemukakan Malik dkk (2018) menyatakan bahwa strategi yang dapat diterapkan dalam pengembangan usahatani gula kelapa dengan meningkatkan daya saing melalui koperasi atau asosiasi untuk pemasaran bersama.

\section{Strtategi W-T}

Strategi WT merupakan strategi yang dilakukan dengan cara meminimalkan kelemahan dan menghindari ancaman yang ada. Strategi WT yang dapat diterapkan pada home industri gula kelapa di Kecamatan Jeruklegi Kabupaten Cilacap adalah sebagai berikut :

1. Melakukan peningkatan kualitas produk guna meningkatkan daya saing terhadap masuknya produk gula kelapa dari wilayah lain dengan memanfaatkan teknologi media sosial .

a. Meningkatkan mutu produk dan tampilan kemasan sehingga meningkatkan daya saing produk

b. Memanfaatkan media sosial untuk mempromosikan produk gula kelapa

2. Mendorong peningkatan produksi gula kelapa sebagai unggulan lokal daerah agar mendapat dukungan secara penuh dari pemerintah daerah setempat

a. Melakukan kerjasama dengan pihak Pemda setempat untuk mendapat dukungan penuh dalam produksi gula kelapa sebagai unggulan lokal daerah

b. Meningkatkan mutu produk dan tampilan kemasan sehingga menjadi produk unggulan lokal daerah.

\section{KESIMPULAN DAN SARAN}

\section{Kesimpulan}

Berdasarkan hasil penelitian strategi marketing mix home industri gula kelapa di Kecamatan Jeruklegi

Kabupaten Cilacap dipengaruhi oleh faktor-faktor internal mencakup yaitu tersedianya pohon kelapa yang diambil niranya, kegiatan produksi gula kelapa dilakukan secara kontinue, lokasi usaha olahan gula kelapa yang cukup strategis, harga produk gula kelapa mampu bersaing, tersedianya tenaga kerja pengrajin gula kelapa, pengalaman pengrajin yang sudah lama menekuni usaha olahan gula kelapa, kepemilikan modal usaha pengrajin secara mandiri, keterbatasan jumlah pohon kelapa pengrajin, kualitas produk belum memiliki keseragaman (rasa, warna dan bentuk cetakan), minimnya sumber informasi pemasaran sehingga produk gula kelapa dijual ke tengkulak, Tingkat teknologi produksi dan pengemasan produk secara tradisional, keterbatasan modal usaha yang dimiliki pengrajin, pengrajin belum melakukan manajemen pembukuan dalam usaha gula kelapa dan belum terdapatnya kesadaran para pengrajin membentuk kelompok/koperasi guna pengembangan usaha produk gula kelapa.

Faktor-faktor eksternal mencakup Kondisi geografis yang mendukung agroklimat pohon kelapa, Peluang pasar olahan gula kelapa cukup tinggi baik pasar domestik maupun internasional, Produk gula kelapa sebagai produk substitusi gula pasir/gula aren, Terdapatnya hubungan kemitraan antar pelaku pengrajin gula kelapa, 
Terdapatnya pembinaan / kebijakan PEMDA dan instans terkait dalam mendukung pengembangan tanaman kelapa, Adanya perubahan iklim yang mempengaruhi kualitas nira, Adanya perubahan iklim yang mempengaruhi kualitas nira, Terdapatnya produk olahan gula kelapa yang dihasilkan pengrajin dari luar wilayah, Pembinaan terhadap pengrajin gula kelapa oleh pihak PEMDA dan instansi terkait bersifat insidental, Harga produk ditentukan sepihak oleh pengepul sehingga pengrajin sebagai penerima harga, dan Belum terbentuknya kelompok pengrajin gula kelapa atau asosiasi untuk pemasaran bersama.

Posisi home industri gula kelapa di wilayah Kecamatan Jeruklegi Kabupaten Banyumas berada pada fase I (Daerah Agresif) dengan strategi utama yang diterapkan adalah strategi SO yaitu 1) Mengoptimalkan kondisi geografis yang mendukung agroklimat SDA dan SDM pengrajin dalam memproduksi produk gula kelapa secara kontinue dengan harga produk gula kelapa yang mampu bersaing, 2) Mengoptimalkan kegiatan produksi secara kontinue guna menangkap peluang pangsa pasar tinggi baik domestik dan internasional dengan harga bersaing sebagai produk substitusi melalui hubungan kemitraan antar pelaku pengrajin gula kelapa. Memaksimalkan ketersediaan bahan baku nira untuk memanfaatkan peluang menjadikan olahan produk gula kelapa dengan harga bersaing.

Alternatif strategi yang dapat dilakukan yaitu : a) Meningkatkan kualitas tenaga kerja SDM pengrajin melalui kegiatan pelatihan dan ketrampilan guna menghasilkan peningkatan produk gula kelapa bagi pengrajin, b) Melaksanakan efisiensi pengelolaan bahan baku nira guna menciptakan produk gula kelapa beragam (mutu, rasa, bentuk seragam) dan melakukan standarisasi pengolahan produk gula kelapa agar produk mampu bersaing di pasar domestik dan pasar internasional serta c) Mengembangkan terciptanya kemitraan kelembagaan antara pengrajin, saluran pemasaran/pedagang dan pemerintah.

\section{Saran}

Berdasarkan kesimpulan yang diperoleh dari penelitian ini disarankan pihak pengrajin gula kelapa segera membentuk kelompok/koperasi gula kelapa yang menjadi wadah belajar dan bekerja bersama, mengatasi permasalahan bersama guna meningkatkan kekuatan posisi tawar pengrajin guna peningkatan pendapatan pengrajin. Salah satunya dengan melakukan diversifikasi olahan produk gula kelapa menjadi gula semut organik yang memiliki nilai harga jula lebih tinggi.

\section{DAFTAR PUSTAKA}

Anonim. 2015. Monografi Kecamatan Jeruklegi. BPP Jeruklegi. Kabupaten Cilacap.

Anonim. 2019. Data Rekapitulasi Home Industri Gula Kelapa Kabupaten Cilacap. Dinas Tanaman Pangan Dan Kehutanan Kab Cilacap.

Budiningsih,S dan Watemin.2012. Pola Pengembangan Kewirausahaan Petani Pengrajin Gula Kristal . Hasil Penelitian Unggulan Program Studi Agribisnis Fak Pertanian UMP.

Budiningsih, S. dan Watemin .2014. Pola Pengembangan Kewirausahaan Petani Pengrajin Gula Kelapa Kristal. Jurnal AGRITECH Vol XVI No.1 Juni Thn 2014. Fak Pertanian UMP.

Budiningsih, S. dan Watemin. 2015. Analisis Profitabilitas Dan Nilai Tambah Agroindustri Gula Kelapa Berbasis Potensi Lokal. Prosiding pada Semnas LPPM UMP Sabtu, 26 September 2015 di Aula AK Anshori.

Budiningsih, S. dan Kusbandiyah A. 2015. Strategi Optimalisasi Entrepeneur Petani Pengrajin Gula Kristal Untuk Peningkatan Diversifikasi Produk. Laporan Penelitian. Fak Pertanian. UMP (Tahun Kedua).

Budiningsih S, Muji Rahayu TS dan Mundjiati R. 2017. Strategi Pengembangan Gula Kelapa di Perdesaan. Jurnal AGRITECH Des 2017 p77-88 FP Univ Muhammadiyah Purwokerto.

David,F.R. 2006. Manajemen Strategi : Konsep. Edisi Sepuluh. Salemba Empat, Jakarta.

Kotler Philip. 2005. Manajemen Pemasaran Jilid 2. Jakarta.

Kotler P Dan Keller L (2012). Marketing Communications. Jakarta : Airlangga.

Malik, W.A., Ferichani,M dan Widiyanti, E. 2018. Strategi Pengembangan Usahatani Gula Kelapa di Kecamatan Puring Kabupaten Kebumen, Jurnal SEPA 14 (2) : 105-113.

Pudyastuti NN dkk. 2019. Pengembangan Agroindustri Gula Kelapa di Kabupaten Cilacap : Kajian Strategi Marketing Hasil Pertanian. Jurnal Kawistara Vol 9 No2, Tgl 22 Agustus 2019 Hal 139-149.

Rangkuti, F. 2006. Analisa SWOT Teknik Membedah Kasus Bisnis. Gramedia.Jakarta

Singarimbun, M. 1989. Metode Penelitian Survey. LP3ES. Jakarta. 
Syahza, A. 2012. Ekonomi Pembangunan :Teori Dan Kajian Empirik Pembangunan Pedesaan. Pekanbaru : UR PRESS 